\title{
THE FLIPPED CLASSROOM METHOD APPLICATION AT THE THEORY AND PRACTICE OF TRANSLATION LESSONS IN HIGHER EDUCATIONAL ESTABLISHMENT
}

\section{ЗАСТОСУВАННЯ МЕТОДУ ПЕРЕВЕРНУТОГО НАВЧАННЯ НА ЗАНЯТТЯХ ІЗ ТЕОРІЇ І ПРАКТИКИ ПЕРЕКЛАДУ У ЗАКЛАДІ ВИЩОЇ ОСВІТИ}

\begin{abstract}
The article is devoted to the teaching methods at the higher educational establishment. The research presents the necessity to select the appropriate method for teaching courses in higher educational establishment. It represents the method of flipped classroom at the theory and practice of translation lessons. The topicality of the method is caused by modern changes and reforms in higher education and growing interest in the courses connected with foreign languages applying. The following method is used effectively in higher education to be applied by adult audience, mainly by undergraduates. It is highlighted that the flipped classroom method is based mainly on the independent work of the students on the basis of the task or material given on the topic by the teacher. The essence of the method was to research the suggested topic more profoundly and to make it more understandable and clear, first of all, for themselves and for presenting the material learnt to the audience and ability to implement it into practice. The article is aimed at giving the example of the lesson in theory and practice of translation prepared by the students themselves on certain topic and conducted among the students of the higher educational establishment. The material of the lesson example contains the topic on the different types of equivalents while interpreting. The theme is topical in theory and practice of translation. It is stated that there is a distinction between the equivalent, analogue, descriptive types of translation and contextual replacements. The examples of translation from source language into target language in different types are given in the main part of the article. Different techniques of translation are presented in the article. The article demonstrates the effective organization of work for students during the lessons in higher educational establishment in contrast to classical model of teaching and studying.

Key words: flipped classroom method, theory and practice of translation, higher education, equivalent interpretation, undergraduate, foreign language.
\end{abstract}

Статтю присвячено методииі навчання у вищому навчальному закладі. Дослідження вказує на необхідність вибору відповідної методики викладання дисципліни у вищому навчальному закладі. Представлено метод перевернутого навчання на уроках теорії і практики перекладу. Актуальність методики зумовлена сучасними змінами $і$ реформами у вищій освіті, а також зростанням інтересу до курсів, пов'язаних із застосуванням іноземних мов. Наведений нижче метод ефективно використовується у вищих навчальних закладах для застосування дорослою аудиторією, передусім студентами. Підкреслено, що метод перевернутого навчання ґрунтується переважно на самостійній роботі студентів на основі завдання чи матеріалу, поданого викладачем за певною темою. Суть методу полягала в тому, щоб глибше дослідити запропоновану тему, зробити ії більш зрозумілою насамперед для себе і під час подання матеріалу для аудиторії, а також у можливості втілити цей матеріал на практиці. Метою роботи $\epsilon$ наведення прикладу уроку із теорії і практики перекладу, підготовленого самими студентами вищого навчального закладу на певну тему. Матеріал уроку містить тематику про різні типи відповідників під час усного перекладу. Тема $\epsilon$ актуальною для теорії і практики перекладу. Зазначено, що існує відмінність між еквівалентним, аналоговим, описовим типами перекладу та контекстними замінами під час перекладання. В основній частині статmі наведено приклади перекладу за допомогою його різних відповідників із мови оригіналу на цільову мову. У статті представлено різні техніки перекладу. Показано есрективну організацію роботи студентів на заняттях у вищому навчальному закладі на відміну від класичної моделі викладання і навчання.

Ключові слова: метод перевернутого навчання, теорія і практика перекладу, вища освіта, еквівалентний переклад, студент, іноземна мова.
Statement of the problem in general and its connection with important scientific or practical tasks. Nowadays higher education is developed according to the existing situation in the society. Different external factors influence the quality and mode of conducting the classes. Methods of teaching and studying differ depending on courses provided by the university curricula are required by the necessity to continue developing an effective system of education in higher educational establishment under the pandemic conditions.

In modern higher education there is an emphasis on promising courses that attract attention of a great number of students. The English language and other similar courses like theory and practice of translation etc. belong to such courses. The course connected to the process of translation from source language into target language is not easily understood by the group of undergraduates. It requires mastering basic knowledge of the English language and gaining of translation skills using active and passive languages of an interpreter or a translator. Theory and practice of translation is one of the most difficult and core courses for humanitarian direction, in particular for future specialists in English, international relations etc. It is not always easily explained by the teacher, so it could be a challenge for a student to swap roles with the teacher and take advantage of the situation 
to understand some topic on their own and practise it at the lessons at university.

There are various ways to teach English and make it interesting for students to be involved into the process. The flipped classroom method is one of the methods of blended learning that allows students to participate in the educational process directly being partners with a teacher. The idea of the method is that students get acquainted with the content of the lesson at home and implement the knowledge gained into practice at university.

The flipped classroom method develops critical thinking of students and enables to search for the information, analyze it, select the most important items and implement their understanding into practice.

Analysis of recent research and publications. The topic of the flipped classroom method of the English language teaching is not new in the scientific literature. The notion of the approach started in 2000 and was introduced by Maureen Lage, Glenn Platt, and Michael Treglia's for their paper entitled "Inverting the Classroom". In 2007 the flipped classroom method was implemented by the teachers from Colorado Jonathan Bergman and Aaron Sams who used the method to help absent students on sick leave to catch up with others in the classroom. That method became popular in science after 2014. Z. Turan and B. Akdag-Cimen researched the flipped classroom method in English language teaching.

Selection of previously unsolved parts of the general problem. The issue of the flipped classroom method application at the theory and practice of translation lessons was not earlier solved in scientific research.

Formulation of the goals of the article (task statement). The goal of the article is to demonstrate practical performance of the students' understanding of the topic of the lesson using the flipped classroom method.

Presentation of the main research material. The task for the flipped classroom was given to the undergraduates at the lesson of theory and practice of translation by the teacher. The topic was about different types of equivalents while interpreting according to the curriculum of the course. The undergraduates' task was to research and provide the appropriate material to understand the topic and be able to distinguish between the types of equivalents in interpretation process in practice.

Any kind of translation or interpretation needs deep knowledge of a target and source language. It is very essential not only to translate words and phrases but also convey their contextual-emotional meaning. In other words, it is necessary to feel colouristic of the source language, its peculiarities while translating any message into the target language. Following this main thought helps to achieve the adequate and full translation or interpretation.

Interpreters should use four main methods of translation. They are the following: equivalent, analogue, descriptive translations and contextual replacements. The first three methods are commonly used and widely known because they are registered in dictionaries, but the fourth one is occasional. According to I. Byk the interpreter has to look for it in the context [1].

The explanation of these methods should start with the simplest one, which is the equivalent translation. It is worth underlining that adequacy is the ratio of the source and final texts, which takes into account the purpose of the translation. In the case when all terms and their combinations are translated correctly and the translation is understandable to the specialist, such a translation of a text can be considered adequate. I. Byk's states that equivalent translation is the only possible translation of a word or an expression, its meaning in the language of the translation corresponds to the meaning of the lexical unit of the original language and is independent of the context. The definition of equivalent translation can be found in different scientific studies. It is advisably to mention N. Kryzhanovska's thought that "equivalent is a constant lexical compliance which precisely coincides with a word meaning" [3, p. 201]. Equivalents are most often translated into word combination, phraseological and set expressions, special terms, proper names, geographical names, as well as historical, ethnographic and other realities that have only a traditional translation in other languages as shown in Table 1.

Equivalent translation

\begin{tabular}{|l|l|}
\hline \multicolumn{1}{|c|}{ Usage } & \multicolumn{1}{c|}{ Ехатрlеs } \\
\hline Special terms, proper names, geographical names & $\begin{array}{l}\text { internationalization - інтернаціоналізація } \\
\text { commander-in-chief - головнокомандувач } \\
\text { Vaclav Havel - Вацлав Гавел } \\
\text { the Czech Republic - Чеська республіка } \\
\text { the Prague Spring - Празька весна }\end{array}$ \\
\hline Word combination & $\begin{array}{l}\text { national minority - національна меншина } \\
\text { national language - державна мова } \\
\text { national industry - вітчизняна промисловість }\end{array}$ \\
\hline Idiomatic/phraseological and stable expressions & $\begin{array}{l}\text { double-edged sword - палка з двох кінців } \\
\text { stumbling block - камінь спотикання } \\
\text { soldier of fortune - найманець }\end{array}$ \\
\hline
\end{tabular}


The next step should be dedicated to the explanation of analogue translation, its meaning, ways of its conveying into other language and its usage while translating a message. Analogue translation implies the choice of one of several possible synonyms. The analogue is not a valid correspondence between the word or the word of the original, and its choice is always determined by the context. This method is more complicated because the interpreter has to make a decision and choose one of the synonyms suggested in the dictionary.

For better understanding the scientificity of every method it is worth approving by examples:

- Comprehensive - обширний, всебічний, всеохопний, вичерпний

Was this information comprehensive or no?

Ця інфрормація вичерпна чи ні?

Social - суспільний, громадський

They pursue an active social life.

Вони ведуть активне громадське життя.

A lot of scientists in the field of theory of translation research the phenomenon of descriptive translation because it replaces the word or phrase of the original with a description or explanation and widely used to convey the essence of utterance. Also, this method of translation is used in cases where no other correspondence exists. It should be used when the loan translation is ambiguous and can't be understood by a target language reader. As a rule the most of the non-equivalent proverbs, sayings and catch-phrases are rendered into the target language. While doing the descriptive translation, one must keep in mind that the translation has to display precisely the main sense of the concept designated by the term; the description shouldn't be excessively detailed; the syntactic structure of a phrase shouldn't be difficult [3, p. 202].

To understand this method of translation the examples, which are the most accurate and available for students' comprehension must be chosen:

- One-to-one - без участі третьої сторони;

- Liquor-control regulations - регулювання виготовлення, збуту та споживання міцних спиртних напоїв;

- Conscientious objector - особа, яка відмовляється від військової служби, посилаючись на свої моральні, релігійні чи політичні переконання [4].

As descriptive translation method complicates the structure of a sentence, it is worth using contextual replacements, which imply the refusal to use existing equivalents or analogues due to the peculiarities of the context, or rather the unusual use of a word or phrase in a particular context.

According to I. Byk, contextual replacements can be divided into five independent techniques of translation:

- concretization of concepts;

- generalization of concepts;
- logical development in translation;

- antonymic translation;

- loss-of-meaning compensation [1].

I would like to highlight the most common cases of usage of the given technique, as concretization, generalization and antonymic translation.

Some groups of lexical units require concretization in translation. This is due to the difference in the proportion between abstract/desemantized and concrete words in the source and target languages [2].

Contextual concretization is mostly used for:

1) verbs with wide meaning like be, get, take, give, have, make, do, say, come, go, turn; they are usually translated by means of more specific words and expressions:

These aircraft are $\$ 50$ million each. - Ці військові літаки коштують 50 млн доларів кожен.

This poster is really worn out - it will really have to go. - Цей плакат дуже потертий - його справді доведеться зняти.

2) expressions with there is/are:

There are many political parties in that organization. - У тій організації налічуєеься багато політичних партій.

There is an awful restaurant nearby. - Неподалік розташований жахливий ресторан.

The opposite of concretization is generalization of concepts that is used in order to avoid expanded explanations or footnotes. If the specific name of an object, phenomenon, etc. may be unfamiliar to the reader, the interpreter or translator replaces it with a generic concept. In the example "Javelin missiles", we understand that it is the name of the anti-tank missiles produced by the United States and the sentence can be translated in the following way: "американська зброя".

Antonymic translation is used when a translator or interpreter conveys the opposite meaning of a given phrase or clause usage.

Antonymic technique is often used for:

1) translation of some phrasal verbs, set expressions and specific phrases:

The state donation came up short some years ago. - Декілька років тому державні дотації були недостатніми.

Banks terminated the credit agreement because the debtor had turned out to be a broke. - Банки припинили дію угоди про кредит, оскільки боржник виявився банкрутом.

2) translation of the words with «hidden» negation like fail, ignore, miss, prevent, defy:

The government has failed to conduct vaccination campaign successful. - Уряду не вдалось провести успішну кампанію з вакцинації.

The problem of nuclear weapon defies solution. Проблема ядерної зброї не піддається розв'язанню.

Thus, an interpreter or translator takes the responsibility of accurate translation applying any technique, 
which conveys the exact meaning of a text in one language into another one.

Conclusions. The flipped classroom method is appropriate and effective in higher education because students are ready to find out more about certain topic using different resources and are able to present the information selected in the process of preparation. Students have opportunity for independent work with the material suggested by the teacher and are able to present their own understanding of the subject in an easy and clear way. They understand the topic from inside and can implement the obtained knowledge into practice.

To further prospects we can refer researches of the flipped classroom method application to other majors in higher education. Such findings are very useful for students to get prepared for differentiated studying and obtaining the qualifications in different areas of science.

\section{REFERENCES:}

1. Бик I. С. Теорія і практика перекладу : конспект лекцій. Львів : ЛНУ ім. І. Франка, 2005. 240 с.

2. Панченко О. І. Теорія і практика перекладу : конспект лекцій. Дніпропетровськ, 2008. URL: https:// textarchive.ru/c-2419931-pall.html (дата звернення: 11.11.2021)

3. Kryzhanovska Ye. H. The peculiarities of the translation English maritime terms into Ukrainian language. Young scientist. 2018. № 2(1). P. 201-204.

4. Turchyn D. English for international relations: textbook for students of higher educational establishments. Vinnytsia: Nova Knyha, 2011. 256 pp. 